\title{
ANALOGY AS A CHILD CENTRIC APPROACH TO TEACH: AS SEEN BY A HIGH SCHOOL TEACHER
}

\author{
Pinaki Chowdhury \\ Mpumalanga Department of Education, South Africa
}

\begin{abstract}
The scarcity of trained man power in the field of science and technology has become a growing phenomenon today. Thus, we are still facing the same challenge country wide. With the multidimensional increase in the field of science and technology, there is a huge shortage of expert workforce in the field of STEM. The numbers of students who qualify for admission into higher educational institution in STEM field is less than required. Our old age school systems from our country sides have failed to fulfill the need of this time. In addition, most rural schools lack basic facilities in terms of the resources required for better learning. Therefore, the author suggests the use of analogy as a powerful tool for a child centric education in rural schools with less resource.
\end{abstract}

Keywords: Rural schools, stem education, analogy, child centric education.

\section{Introduction}

A study by Roe (1952) stated that "the recruitment of qualified young people into science is a growing problem in our society. Hence, where and how shall we find them?" (Joyce \& Farenga, 1999). Thus, this shows that the scarcity of trained man power in the field of science and technology is an old phenomenon. Nevertheless, we are still facing the same challenge country wide. With the multidimensional increase in the field of science and technology, there is a huge shortage of expert workforce in the field of STEM.

South Africa is also facing the shortage of STEM related workforce. A report by Woolard et al. (2005) in HRD review-2003, chapter twenty, projected a need of 5207 new doctors in South Africa for the period 20012006. In 2001, the number of doctors was 34370 (Woolard et al., 2005). Furthermore, SAT monitor-2010 reported 36912 doctors in 2010 in South Africa, which is much less than the projected total figure required in 2006. Therefore, it will be proper to argue that it is important to address this 
problem of man power shortage in the STEM field. This is possible by addressing the problem of the admission of qualified high school STEM graduates to tertiary institutions. A cohort study by Scott et al., 2007 indicates that the numbers of students which qualifies for admission to higher educational institution in STEM field is less than required.

\section{Observation}

The problem of manpower shortage in STEM related fields could be solved if more and more students are introduced to study physical sciences at high school level and if they are provided with qualitative education. However, learners may need an early and better introduction in the field of science and technology to perform at high school level. This is beyond the scope of my present discussion. Thus, the aim of this study is to provide a guideline for a better teaching environment to our existing high school physical science learners with a special attention to the rural country sides.

Based on my understanding, the lack of conceptual understanding and reasoning ability amongst the STEM learners, especially the rural learners, makes them non-performer. Several studies have indicated the presence of student's misconceptions of topics in chemistry. Consequently, the reviews of chemistry misconceptions was done by "Andersson (1990), Bodner (1991), Krajcik (1991), Nakleh (1992), Gabel and Buence (1994), Wandersee, Mintzes, and Novak (1994), Stavy (1995), and Gabel (1999)”. The Council on Higher Education (2007) study (Scott et al., 2007) suggest that growth in the 'science and economic-based fields' is essential for meeting the national needs of South Africa. Thus, this seems to be a challenge due to the persistently low levels of school performance in Mathematics and science in South Africa. Effective teaching and learning in the field of science education, means a better participation of the youths in the field of application of science in a day to day situation.

Subsequently, a present scenario suggests that our system has failed to provide an effective teaching environment to our rural learners. Our rural classes are mostly over-populated and the teachers follow a one-way teacher's lecture method. The absence of technology in class teachers and curricula implementers, both believe that practicing old questions is a better way of learning. Writing more tests and assignments seems to be a better way of teaching. Therefore, the long year practice of these methods has only produced non-performers! Students are always busy either writing notes or writing answers to old questions. As a result, this ultimately inhibits the cognitive growth of the students. In this process of note taking and memo writing, high school students merely act as a cyclostyling machine. On the other hand, it is not possible to convert all rural classes into smart classrooms 
(refer Ong \& Ruthven, 2010). As a result, all-inclusive effective science education is becoming a myth.

Furthermore, to ensure better participation in the STEM field and in producing a better STEM-oriented workforce, it is essential that proper interest and understanding in science is developed amongst high school learners. This can only be done by a student-centric science teaching module. However, a study by Ong \& Ruthven (2010) showed that student-centered approach is the best way towards an effective teaching-learning process. Students come to a class with certain preconceptions and if their initial understanding is not engaged, they may fail to grasp the new concepts and information they were taught. Other times, they may learn them for the purpose of a test, and revert to their preconceptions outside the classroom (Bransford et al., 2005).

\section{Suggestion}

The use of model and analogy may possibly improve the situation of STEM education in rural schools. Teaching with analogy by Glynn (1991), Focus action reflection by Harrison and Treagust (2006), and multiple analogies by Chiu \& Lin (2005) suggest the usefulness of analogy as a tool for promoting meaningful learning. In spite of being considered to be a double-edged sword (Harrison \& Coll, 2007; Harrison \& Treagust, 2006), analogies are widely used. There is a substantial body of literature which reports on the benefits of teaching with analogies, and their success (Coll, France, \& Taylor, 2005; Taylor \& Coll, 1997; Dagher, 1995; Brown, 1993; Arthur et al., 1990). In addition, Gobert et al., 2011 quoted the study of Sins et al. (2009) which shows a positive relationship between the students' understanding of models and the depth of cognitive processing. Therefore, we may conclude that Analogies/Models in teaching science may effectively help to overcome students' misconceptions and naïve understandings about science process and content.

According to constructivism theory, learning is a self-activating response to challenges, dissonance, or discrepancy, rather than a passive encoding of experience (Resnick, 1983; Anderson, 1990; Lawson, 1993). Furthermore, number of constructivist research (Carey, 1986; Sandoval, 1995) suggests that prior knowledge has a useful consequence in learning. As we learn, we manipulate ourselves within the new context from our prior knowledge. Prior knowledge is the concept required for our further knowledge. Several studies at different levels have reported the lack of conceptual understanding (prior knowledge) amongst the learners (Author, 1993; Banerjee, 1991; Driver and Errickson, 1983). Knowledge is constructed by individual learners by interaction within the activity among users, technology, and environment which is all within a context. Chiu and 
Lin (2005) suggest that "no two events, experiences, or phenomena are same. To learn novel things, it is necessary to find similarities between things that are different and then create a bridge between them". However, when we compare a known concept with new a concept, and create a relation to conceptualize the new, we refer to this as "Analogy". Analogy makes the thing happen. In addition, analogy makes interactions more effective with the learner and the environment. Chiu and Lin (2005) also recommend the inclusion of a well-planned analogy in textbooks.

\section{A Human Model of Atom}

A study on grade twelve students conceptual understanding on current electricity was conducted by me during 2007-2008. Thus, the responses I received are given below. This was done to find student's previous knowledge before introducing the topic "Flow of Current in a Liquid”.

Pre-knowledge Study on Electrochemistry:

\begin{tabular}{|c|c|c|c|}
\hline Number & Question & $\begin{array}{c}\text { Typical Answer } \\
\text { electricity? }\end{array}$ & $\begin{array}{c}\text { In every case, students were very prompt to say that the flow } \\
\text { of charges is responsible for the current electricity. }\end{array}$ \\
\hline 2 & $\begin{array}{c}\text { What charges } \\
\text { are present in an } \\
\text { atom? }\end{array}$ & $\begin{array}{c}\text { Almost every student identified the positive and negative } \\
\text { charges present in an atom. Some did say proton \& electron, } \\
\text { instead of saying positive and negative. }\end{array}$ \\
\hline 3 & $\begin{array}{c}\text { Can positive } \\
\text { charges move in } \\
\text { a wire? }\end{array}$ & $\begin{array}{c}50 \% \text { of the students felt that positive charges do move in the } \\
\text { wire. Some referred to a dry cell having + sign as a proof of } \\
\text { flow of positive charges in a wire. 30\% of the cases } \\
\text { definitely said positively charges cannot move. Others were } \\
\text { confused on the result. }\end{array}$ \\
\hline 4 & $\begin{array}{c}\text { How does } \\
\text { current flow } \\
\text { from a dry-cell? }\end{array}$ & $\begin{array}{c}\text { Almost all said that current flows from positive to the } \\
\text { negative end. No one could realize that there is nothing } \\
\text { physical that flows between positive to the negative end of a } \\
\text { dry cell. }\end{array}$ \\
\hline 5 & $\begin{array}{c}\text { What is this } \\
\text { current } \\
\text { electricity? }\end{array}$ & All students again said that this is the flow of charges. \\
\hline
\end{tabular}

Therefore, the study above clearly indicates that students have certain misconceptions about the flow of current through a conductor and the role of electrons.

In addition, we must understand that it is easy to write on a clean board than on a board that is already full with previously written matters. The same holds true in cases of teaching-learning activities. It is really difficult to teach a group of learners who are loaded with a lot of misconceptions. Rural learners in this part of the world are most badly informed or less informed. Thus, it should be the first and foremost duty of 
the teacher to remove the misconceptions of the learners before pushing the correct concepts in their mind.

However, my aim was to make these students have an understanding about the flow of current in an electrolyte. I decided to create an analogy using a situation that students are familiar with.

Students were asked to consider the following:

Compare an atom as a man or women.

Every men and women wear dresses to cover their body. This includes undergarments and clothes over under garments, hat, socks, shoes etc.

Similarly, atoms wear electrons over its main body (nucleus).

The main body of a human being is made of bone, flesh etc.

Similarly, the main body of an atom (nucleus) is made by combining protons and neutrons.

Under normal situation, a person cannot be naked; hence they perform their work wearing some kind of dresses.

Similarly, under normal situation, an atom always holds the electrons surrounding its nucleus.

A person may remain without some of the dresses or wear some extra clothing, but does not look odd (e.g. a hat, sun glass etc.).

Similarly, an atom may lose or gain some electrons (outer electrons) without causing any change in its appearance. But to understand that, it changes some of the atomic properties. ( Ions and Atoms )

This makes a charged atom (ions), but we cannot remove the inner electrons of an atom. As we do not remove our undergarments and some other dresses in public.

Using the above analogy, students explained the outer electrons of metal atoms. Also, they compared a hat over the head of a person that may be moved from one head to the other; hence making a continuous flow of hats (current).

Here, the intention was to make students understand the flow of current through a solution. Students were asked if they can swim keeping their hat over their head. Thus, some argued to have the hat tied-up over their head. Students were asked about a real situation: what happens if someone who wants to swim is having a hat on his head? Reply came as: Everyone should keep their hat beside the pool. Thus, here comes the overlapping of Analogy. Author put forward the idea that "the metal atoms want to swim in water (Electrolyte)". They have to keep their outer electrons (hats) off. Positive ions will be moving in the electrolyte. Some negative ions will also be there as if hats are tied up to their head! If one is extra imaginative, they may imagine a person having an extra head without a hat. Thus, it wants a 
hat from others so it becomes negative. The rule of the game is that once an atom is charged, it has to go down to the liquid (electrolyte).

\section{Impact}

In the process of developing analogy, each student was found to be an active listener rather than a passive listener. There were definite reactions and expressions from the students. The process was found to develop interest amongst the students in their studies. Consequently, students' responses towards the posed questions were getting more and more logical and correct. This showed that misconceptions were getting removed from the mind of the students. It was of great interest to see that participating students also showed better performance in their regular tests. Therefore, I strongly suggest that similar study should be conducted in a larger scale to establish the usefulness of analogy in classrooms to teach high school science. Clement (1998) also suggested that "more work is badly needed in this field (use of Analogy)".

In conclusion, there may be many different ways to create analogies for explaining atom and its electrical character. The author feels that an analogy should be taken from the students’ environment. Analogy created in this case is simple but very effective for the students as they all had prior knowledge about the swimming pool. The Author also suggests that the use of analogy can effectively improve the conceptual understanding level of the students. More importantly, rural schools that are suffering from resource crunch can effectively use the method of creating analogy to teach different science topics using proper analogy and simple modeling. Therefore, I would like to end by using a quote from Bransford et al., 2000 "There is no particular pedagogic method that may make the learners perfect, but there is one important agreement amongst all research that class-rooms must be learners’ centered”.

\section{References:}

Anderson, J.R. 1990, Cognitive psychology and its implications (3rd ed.), New York, WH Freeman.

Aurther, W.F. Dorothy, T.G. Gabel, J.S. 1990, School Science and Mathematics, 90, 674-682.

Banerjee, A.C. 1991, International Journal of Science Education, 13, 487494.

Bodner, G.M. 1991, Journal of Chem. Education, 64, 385-388.

Bransford, J.D. Brown, A.L. Cocking, R.R. (eds), 2000, National Research Council, National Academy Press, Washington, D.C.

Bransford, J.D. Donovan, M.S. 2005, How Students Learn Science in the classroom, National Academic Press, Washington, D.C. 
Brown, D.E. 1993, Journal of Research in Science Teaching, 30, 1273-1290. Carey, S. 1986, American Psychologist, 41, 1123- 1130.

Chiu, M.H. Lin, J.W. 2005, Journal of Research in Science and Technology, 42, 429-464.

Chowdhury, P. 1993, School Science, 21, 2, 45-49.

Chowdhury, P. 1993, School Science, 21, 4, 24-27.

Clement, J.J. 1993, International Journal of Science Education, 20, 12711286.

Coll, R.K. France, B. Taylor, I. 2005, International Journal of Science Education, 27, 183-198.

Dagher, Z.R. 1995, Journal of Research in Science Teaching, 32, 259-270.

Driver, R. Erickson, G. 1983, Studies in Science Education, 10, 37-60.

Gabel, D.L. 1999, Journal of Chem. Education, 76, 548-554.

Gabel, D.L. Buence, D.M. 1994, Handbook of Research on Science Teaching and Learning, New York, Macmillan.

Glynn, S.M. 1991, The Psychology of Learning Science, Glynn, S.M. Yeany, R.H. Britton, B.K (eds). Hillsdale, N.J.

Gobert, D.J. O’Dwyer, L. Horwitz, P. Buckley, B.C. Levy, S.T. Wilensky, W. 2011, International Journal of Science Education, 33, 653-684.

Harrison, A.G. Coll, R.K. 2007, FAR guide, Using Analogies in middle and secondary science (Google Book).

Harrison, A.G. Treagust, F.D. 2006, Metaphor and Analogy in Science Education, 11-24, Abusen, P.J. Harrison, A.G. Ritchie, S.M (eds). Springer, The Nederlands.

Joyce, A.B. Farenga, S.J. 1999, School Science and Mathematics, 99, 431437.

Krajcik, J.S. 1991, The Psychology of Learning Science, Lawrence Erlbaum, Hillsdale, N.J.

Lawson, A.E. 1993, Journal of Research in Science Education, 30, 12131214.

Nakleh, M.B. 1992, Journal of Chem. Education, 69, 191-196.

Ong, E.T. Ruthven, K. 2010, Research in Science and Technological Education, 1, 25-41.

Resnick, L.B. 1983, Science, 220, 477-478

Roe, A. 1952, Scientific American, 757, 21-25.

Sandoval, J. 1995, Annual Review of Psychology, 46, 355-374.

Scott, I. Yeld, N. Hendry, J. 2007, Higher Education Monitor, No. 6, The Council of Higher Education, Pretoria.

Sins, P.H.M. Saveslsbergh, E.R. van Joolingen, W. van Hout-Wolters, B. 2009, International Journal of Science Education.

Stavy, R. 1995, Learning Science in the Schools, Research Informing Practice, Lawrence Erlbaum, Hillside, N.J. 
South African Transformation Monitor, September 2010, Solidarity Research Institute, South Africa.

Tyalor, N. Coll, R.K. 1997, Australian Science Teachers Journal, 43, 58-64. Wandersee, J.H. Mintzes, J.J. Novak, J.D. 1994, Handbook of Research on Science Teaching and Learning, Macmillan, New York. 